\title{
Cytological Effects of Herbicides and Insecticides on Allium cepa Root Meristems
}

\author{
B. V. Rao, B. G. S. Rao and C. B. S. R. Sharma \\ Department of Botany, Andhra University, Waltair 530 003, India
}

Accepted February 4, 1987

Pesticides represent a very large input of chemicals into our environment (Crosby 1981). The use of pesticides has assumed considerable significance in modern agricultural practices. However, screening of pesticides in different assay systems revealed that some pesticides could have known or unknow mutagenic/carcinogenic effects on the non-target biological systems (Epstein and Legator 1971, Fishbein 1972, Grant 1978). In this context an attempt was made to assess the cytological effects of four pesticides viz., asulum, MSMA, chlorpyriphos and endosulfan using an amenable plant assay system-Allium test (Constantin and Owens 1982, Sharma 1983) and the results are reported here.

\section{Material and methods}

Root meristems raised from common onion (Allium cepa L. $2 \mathrm{n}=16$ ) were used as assay system. Four pesticides tested in this study are two herbicides viz., asulum (Methyl (4-aminophenyl sulfonyl) carbamate and MSMA (Mono-sodium acid methane arsonate) and two insecticides viz., chlorpyriphos $(O, O$-diethyl-O-(3, 5, 6-trichloro-2-pyridyl) phosphorothioate) and endosulfan $(1,4,5,6,7,7$-hexachloro-8, 9, 10-trinorborn-5-en-2, 3, ylendi methyl sulphite). Prior to the initiation of the experiment, treatment solutions were prepared by dissolving the test compounds (by volume) in 1-2 drops of acetone and subsequently diluting in distilled water. The range of test concentrtations selected was below the cytotoxic threshold of each chemical (by $L_{50}$ method) to the test system.

Root meristems of $2-3 \mathrm{~cm}$ length were exposed to the test solutions of different concentrations for one hour followed by recovery periods of $0,4,12,24$ and 48 hours in Hoagland's nutrient solution adjusted to $\mathrm{pH} 7$. Water controls were maintained simultaneously in order to compare the spontaneous aberrations. After the exposure and recovery regimen the root tips were excised, fixed in 3: 1 ethanol-acetic acid and stained by the Feulgen method (Darlington and La Cour 1976). For metaphase studies, both the treated and untreated material were pretreated with $0.05 \%$ colchicine for $2 \frac{1}{2}$ hours, washed and fixed at the end of recovery schedule. For each variable, 5-6 root tip squashes were made and a minimum of 600 cells at anaphase/metaphase were counted in order to assess the clastogenic and turbagenic (Brogger 1979) manifestations.

\section{Observations}

The results are summarised in Tables 1-4. Mitotic index was slightly lowered by all the pesticidal treatments except with endosulfan, where the mitotic activity was higher (Table 4).

In the present study MSMA induced wide-range clastogenic effects like chromosomal and chromatic breaks, 'subchromatid' (interchromatid) connections and heteromorphic chromosomes at metaphase; chromatin bridges and chromosome fragmentation at anaphase (Table 2 and Figs. 1-4). In MSMA and chlorpyriphos treatments, cells containing micronuclei were 
noticed at 2000 and $250 \mathrm{ppm}$ concentrations respectively. In the case of endosulfan, however, micronuclei occurred at all concentrations and their frequency was proportional to the concentration (Tables 2, 3, Fig. 5).
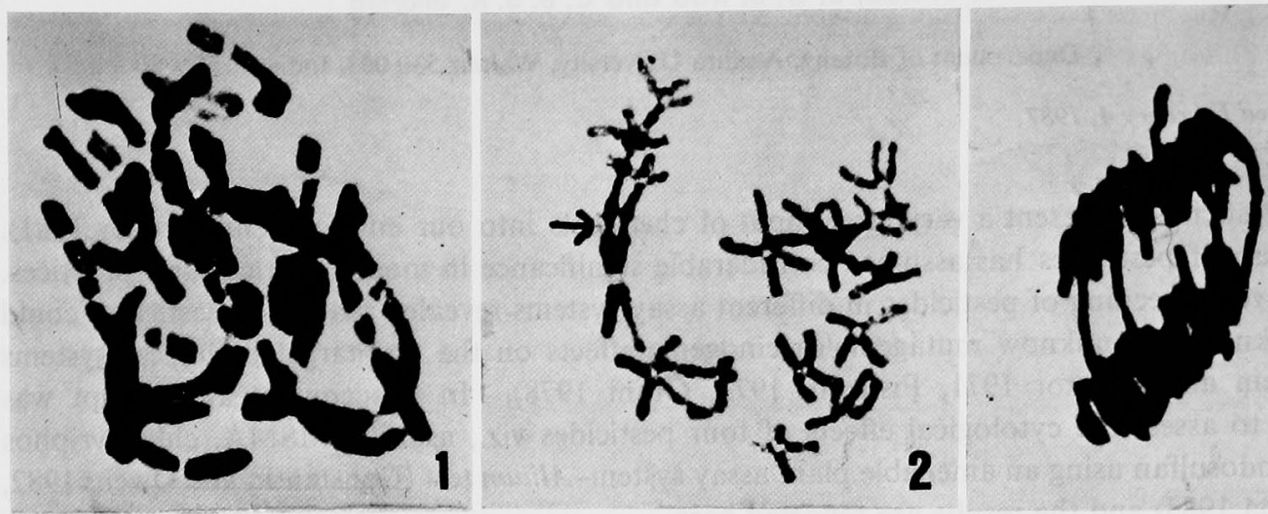

4

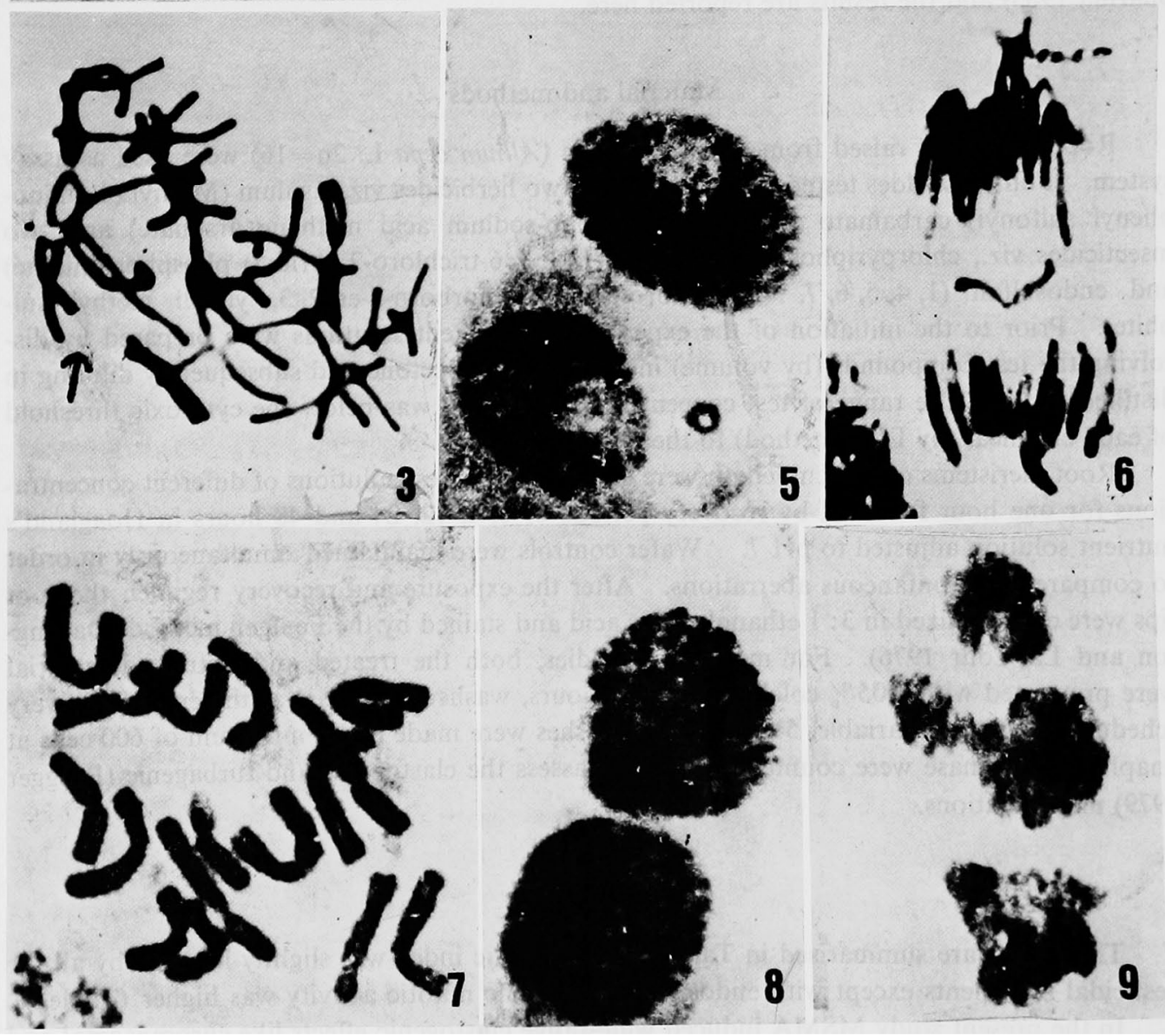

Figs. 1-9. 1, chromosome breaks at metaphase. 2, 'subchromatid' connection at metaphase. 3, heteromorphic chromosome at metaphase. 4, anaphase bridge. 5, micronucleus. 6, lagging and forward chromosome at anaphase. 7, C-metaphase (arrested metaphase). 8, binucleate cell. 9, multinucleate cell. Magnification at $3000 \times$. 
Low frequency of chromatin bridges at anaphase was noticed with asulum and endosulfan (Tables 1, 4, Fig. 4), whereas sticky chromosomes at metaphase were observed with all the test pesticides except MSMA.

All the pesticidal treatments induced scattered anaphases, laggards and forward chromosomes (precocious movement) to varying degrees. The frequencies of these three turbagenic manifestations are pooled and are presented under a single category as chromosome vagrancy (Fig. 6).

Table 1. Mitotic index (MI) and frequencies of clasto- and turbagenicity of asulum monitored in Allium cepa root meristems

\begin{tabular}{|c|c|c|c|c|c|c|c|}
\hline \multirow{2}{*}{$\begin{array}{l}\text { Conc. } \\
\text { in } \\
\text { ppm }\end{array}$} & \multirow{2}{*}{$\begin{array}{l}\text { * Recovery } \\
\text { periods } \\
\text { (hrs) }\end{array}$} & \multirow{2}{*}{$\mathrm{MI} \pm \mathrm{SE}$} & \multirow{2}{*}{$\begin{array}{l}\text { Clasto- } \\
\text { genicity } \\
\text { Ab }\end{array}$} & \multirow{2}{*}{ Sticky } & \multicolumn{2}{|c|}{$\begin{array}{c}\text { Spindle } \\
\text { dysfunction }\end{array}$} & \multirow{2}{*}{$\begin{array}{c}\begin{array}{c}\text { Phragmoplast } \\
\text { dysfunction }\end{array} \\
\mathrm{Bn}\end{array}$} \\
\hline & & & & & $\mathrm{Cv}$ & $C-m$ & \\
\hline \multirow[t]{3}{*}{ Control } & & $7.28 \pm 0.12$ & 0.18 & & 0.40 & & \\
\hline & 0 & $7.16 \pm 0.13$ & 0.20 & & 3.28 & & \\
\hline & 4 & - & & 0.87 & - & 96.05 & 1.50 \\
\hline \multirow[t]{5}{*}{500} & 12 & & & & 2.35 & & 1.12 \\
\hline & 24 & & & & 1.31 & & \\
\hline & 48 & & & & 1.22 & & \\
\hline & 0 & $7.06 \pm 0.15$ & 0.67 & & 1.79 & & \\
\hline & 4 & - & & 1.05 & - & 98.02 & 1.75 \\
\hline \multirow[t]{5}{*}{1000} & 12 & & 0.39 & 0.67 & 2.22 & & 1.67 \\
\hline & 24 & & & 0.86 & 2.14 & & \\
\hline & 48 & & & 0.19 & 2.52 & & \\
\hline & 0 & $6.96 \pm 0.18$ & & & 3.76 & & \\
\hline & 4 & & & 0.20 & - & 98.70 & 2.80 \\
\hline \multirow[t]{5}{*}{2000} & 12 & & & 0.30 & 2.69 & & 1.64 \\
\hline & 24 & & 0.22 & 0.14 & 2.39 & & \\
\hline & 48 & & & & 1.19 & & \\
\hline & 0 & $6.89 \pm 0.16$ & & & 2.02 & & \\
\hline & 4 & - & & 1.69 & - & 99.56 & 5.00 \\
\hline \multirow[t]{3}{*}{3000} & 12 & & 0.27 & 1.62 & 2.26 & & 4.30 \\
\hline & 24 & & & & 1.63 & & \\
\hline & 48 & & & & 1.61 & & \\
\hline
\end{tabular}

* =following one hour pulse treatment; M.I.=mitotic index; S.E.=standard error; $A b=$ anaphase bridge; Sticky $=$ stickiness of chromosomes at metaphase; $\mathrm{CV}=$ chromosome vagrancy; $\mathrm{C}-\mathrm{m}=\mathrm{C}$ metaphase; $\mathrm{Bn}=$ binucleate cells.

Similarly, C-metaphase configurations were noticed with all the test pesticides (Fig. 7). Polyploid cells in the subsequent recoveries were observed only with chlorpyriphos and endosulfan (Tables 3, 4).

Except chloropyriphos, all the test pesticides induced bincucleation (Fig. 8). However, bimitosis and multinucleation were the subsequent abnormalities observed with only MSMA and endosulfan respectively (Fig. 9).

\section{Discussion}

The results presented above clearly indicate that the increse in mitotic indices values in root meristems treated with endosulfan are the result of accumulation of C-metaphase configurations at zero hour recoveries (Badr 1983). However, in all the other chemical exposures 


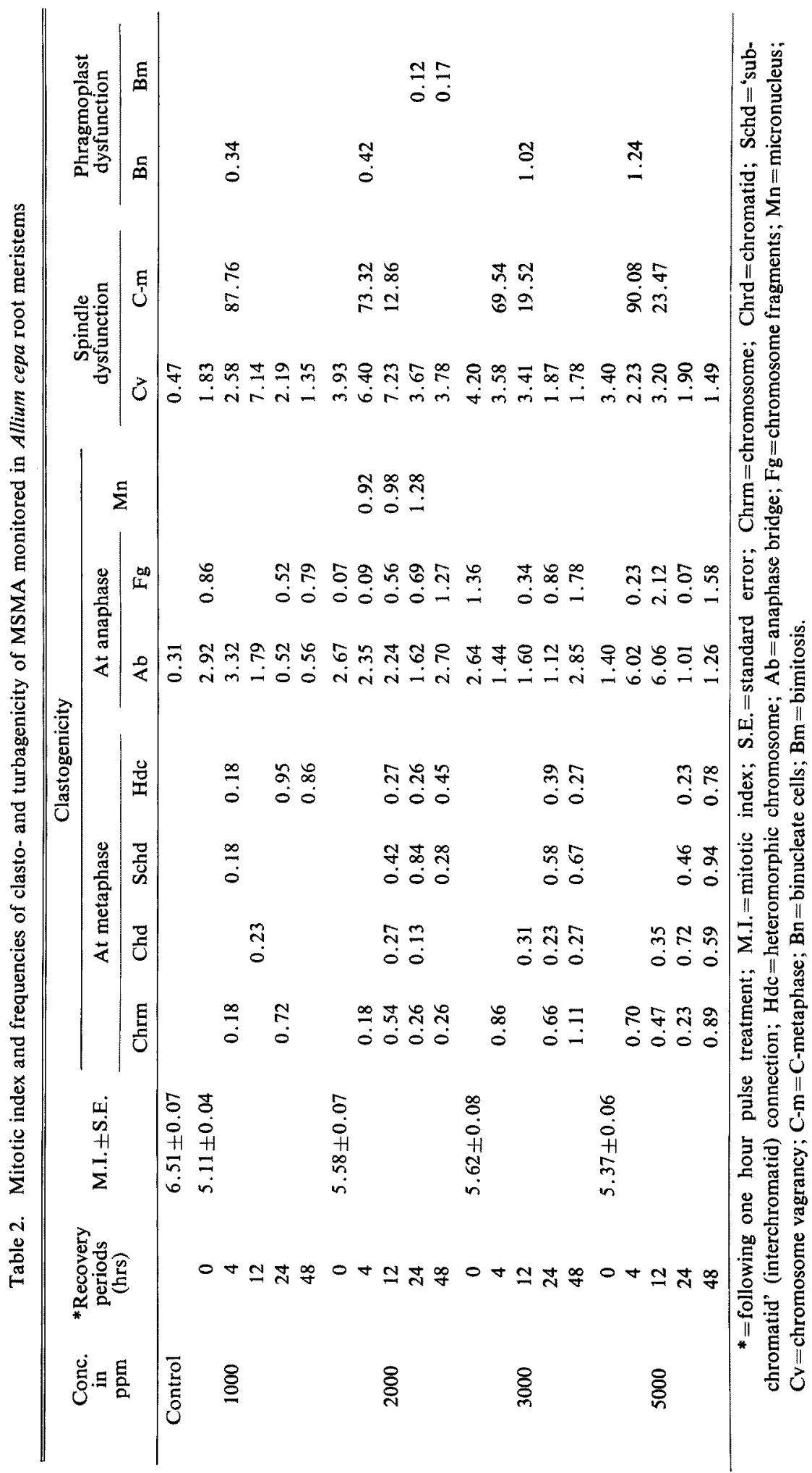


mitodepression was induced. Several herbicides and insecticides have been reported to depress the mitotic activity (Amer and Farah 1976, Badr 1983, de Kergommeaux et al. 1983).

In the present study the arsenic herbicide MSMA is found to be an effective clastogen. Induction of 'subchromatid' connections is the result of true exchanges between homologous or non-homologous chromosomes whereas the presence of hetermorphic chromosomes can be attributable to terminal deletion of one of the chromatids (Rosenkranz and Rosenkranz 1972, Tomkins and Grant 1972, Grant 1978). Agents that act directly on DNA were shown to exert such exchange figures (Bedford and Robinson 1972, Wooder and Wright 1981).

Asulum and endosulfan induced chromatin bridges at anaphase, mostly single; occasionally double and triple bridges were also encountered. Breaking-up of chromosomes followed

Table 3. Mitotic index (MI) and frequencies of clasto- and turbagenicity of chlorpyriphos monitored in Allium cepa root meristems

\begin{tabular}{|c|c|c|c|c|c|c|c|c|}
\hline \multirow{2}{*}{$\begin{array}{l}\text { Conc. } \\
\text { in } \\
\text { ppm }\end{array}$} & \multirow{2}{*}{$\begin{array}{l}\text { *Recovery } \\
\text { periods } \\
\text { (hrs) }\end{array}$} & \multirow{2}{*}{ M.I. \pm S.E. } & \multicolumn{2}{|c|}{ Clastogenecity } & \multirow{2}{*}{ Sticky } & \multicolumn{3}{|c|}{ Spindle dysfunction } \\
\hline & & & $\mathrm{Ab}$ & Mn & & $\mathrm{Cv}$ & $\mathrm{C}-\mathrm{m}$ & Pp \\
\hline Control & 0 & $7.10 \pm 0.11$ & 0.22 & & & 0.39 & & \\
\hline & $\begin{array}{l}0 \\
4\end{array}$ & $6.52 \pm 0.09$ & $\begin{array}{l}0.45 \\
0.56\end{array}$ & & - & $\begin{array}{l}2.49 \\
4.34\end{array}$ & 1.93 & \\
\hline 50 & $\begin{array}{l}12 \\
24 \\
48\end{array}$ & & & & & $\begin{array}{l}4.14 \\
4.67 \\
2.88\end{array}$ & & $\begin{array}{l}0.22 \\
0.19\end{array}$ \\
\hline & $\begin{array}{l}0 \\
4\end{array}$ & $6.55 \pm 0.15$ & $\begin{array}{l}0.71 \\
0.52\end{array}$ & & & $\begin{array}{l}4.43 \\
3.94\end{array}$ & 2.12 & \\
\hline 100 & $\begin{array}{l}12 \\
24 \\
48\end{array}$ & & & & & $\begin{array}{l}2.81 \\
3.67 \\
3.70\end{array}$ & & $\begin{array}{l}0.11 \\
0.36\end{array}$ \\
\hline & $\begin{array}{l}0 \\
4\end{array}$ & $6.68 \pm 0.21$ & 0.24 & & 2.30 & $\begin{array}{l}6.41 \\
3.48\end{array}$ & & 0.11 \\
\hline 150 & $\begin{array}{c}12 \\
24 \\
48\end{array}$ & & 0.51 & & 1.68 & $\begin{array}{l}4.77 \\
3.88 \\
4.84\end{array}$ & & $\begin{array}{l}0.24 \\
0.18\end{array}$ \\
\hline & $\begin{array}{l}0 \\
4\end{array}$ & $6.30 \pm 0.18$ & $\begin{array}{l}0.77 \\
0.97\end{array}$ & & 3.60 & $\begin{array}{l}3.84 \\
2.00\end{array}$ & & 0.99 \\
\hline 250 & $\begin{array}{l}12 \\
24 \\
48\end{array}$ & & 0.67 & $\begin{array}{l}0.86 \\
1.06 \\
0.95\end{array}$ & 1.26 & $\begin{array}{l}2.33 \\
4.12 \\
1.79\end{array}$ & & $\begin{array}{l}0.52 \\
0.08\end{array}$ \\
\hline
\end{tabular}

*=following one hour pulse treatment; M.I.=mitotic index; S.E.=standard error; $A b=$ anaphase bridge; $\mathrm{Mn}=$ micronucleus; Sticky = stickiness of chromosomes at metaphase; $\mathrm{CV}=$ chromosome vagran$\mathrm{cy}, \mathrm{C}-\mathrm{m}=\mathrm{C}-\mathrm{metaphase} ; \mathrm{Pp}=$ polyploid.

by proximal chromatid reunion obsviously gave rise to such cytological abnormalities (Grant 1978).

Micronuclei observed with the three pesticides are resultants of clastogenic events of the cells concerned rather than mitoclastic events (Sparrow and Singleton 1953).

Stickiness of chromosomes observed in this study can be interpreted as the intercalation of the pesticide with DNA leading to entanglement of chromatin threads (McGill et al. 1974). Similar effect has been reported with several other pesticides (Badr 1983, de Kergommeaux et al. 1983).

Apparently, all the chemical exposures impaired spindle mechanisms to varying degrees leading to chromosome vagrancies. 
Similar to carbamate pesticides, asulum and MSMA were found to be the most effective in exerting C-metaphase configurations coinpared to the two other insecticides.

Inhibition of cell plate formation evidently led to the formation of binucleate cells as has been observed now with MSMA and endosulfan. The toxic impact of the pesticides, however, was not consistent (Fourcade et al. 1963).

The present study reveals that the test pesticides exerted wide-range clastogenic as well as turbagenic effects similar to many other pesticides. The results read together with earlier reports on the cytogenetic effects of chlorpyriphos (Amer et al. 1980, Amer and Farah 1983) and endosulfan (Grover and Tyagi 1979, 1980a, b) warrant further investigations on these agrochemicals on a more intensive and extensive basis, since they can effect fertility and may alter the genetic constitution of the crop plants by causing such effects (Wuu and Grant 1966, Ma 1981).

Table 4. Mitotic index (MI) and frequencies of clasto- and turbagenicity of endosulfan monitored in Allium cepa root meristems.

\begin{tabular}{|c|c|c|c|c|c|c|c|c|c|}
\hline \multirow{2}{*}{$\begin{array}{c}\text { Conc. } \\
\text { in } \\
\text { ppm }\end{array}$} & \multirow{2}{*}{$\begin{array}{l}\text { *Recovery } \\
\text { periods } \\
\text { (hrs) }\end{array}$} & \multirow{2}{*}{ M.I. \pm S.E. } & \multicolumn{2}{|c|}{ Clastogenicity } & \multicolumn{3}{|c|}{ Spindle dysfunction } & \multicolumn{2}{|c|}{$\begin{array}{c}\text { Phragmoplast } \\
\text { dysfunction }\end{array}$} \\
\hline & & & $\mathrm{Ab}$ & Mn & $\mathrm{Cv}$ & $\mathrm{C}-\mathrm{m}$ & $\mathrm{Pp}$ & $\mathrm{Bn}$ & Mtn \\
\hline \multirow[t]{3}{*}{ Control } & & $6.99 \pm 0.17$ & 0.12 & & 0.42 & & & & \\
\hline & 0 & $7.21 \pm 0.14$ & & & 2.05 & 2.05 & & & \\
\hline & 4 & & & & 3.79 & 8.05 & 8.27 & 1.26 & \\
\hline \multirow[t]{5}{*}{50} & 12 & & & & 5.14 & & & 2.54 & \\
\hline & 24 & & & 0.28 & 3.82 & & & & \\
\hline & 48 & & & & 4.52 & & & & \\
\hline & 0 & $7.95 \pm 0.23$ & & & 7.74 & 14.50 & & & \\
\hline & 4 & & 0.35 & & 9.32 & 26.40 & 2.58 & 18.75 & 0.59 \\
\hline \multirow[t]{5}{*}{100} & 12 & & 0.46 & & 1.83 & & & 3.63 & 2.64 \\
\hline & 24 & & & 0.35 & 2.97 & & & & \\
\hline & 48 & & & 0.96 & 3.32 & & & & \\
\hline & 0 & $8.26 \pm 0.27$ & & & 5.34 & 17.41 & & & \\
\hline & 4 & & 0.47 & & 3.84 & 35.95 & 1.20 & 16.47 & 0.79 \\
\hline \multirow{5}{*}{250} & 12 & & 0.39 & & 1.80 & & 4.36 & 9.05 & 1.40 \\
\hline & 24 & & & 0.47 & 2.38 & & & & \\
\hline & 48 & & & 1.56 & 2.82 & & & & \\
\hline & 0 & $8.59 \pm 0.21$ & & & 9.38 & 22.30 & & & \\
\hline & 4 & & 0.84 & & 2.04 & 36.36 & 3.49 & 14.97 & 1.50 \\
\hline \multirow[t]{3}{*}{500} & 12 & & 0.93 & & 6.74 & & & 3.88 & 0.53 \\
\hline & 24 & & 0.28 & 2.63 & 3.77 & & & & 1.06 \\
\hline & 48 & & & 4.08 & 2.24 & & & & \\
\hline
\end{tabular}

${ }^{*}=$ Following one hour pulse treatment; M.I.=mitotic index; S.E. $=$ Standard error; An=Anaphase bridge; $\mathrm{Mn}=$ micronucleus: $\mathrm{CV}=$ chromosome vagrancy; $\mathrm{C}-\mathrm{m}=\mathrm{C}$-metaphase; $\mathrm{Pp}=$ polyploid; $\mathrm{Bn}=$ Binucleate cells and $\mathrm{Mtn}=$ multinucleate cells.

\section{Summary}

Cytological effects of two herbicides viz., asulum and MSMA and two insecticides viz., chlorpyriphos and endosulfan were tested on Allium cepa root meristems. One hour pulse treatments were given with test solutions at different concentrations and allowed to different recovery periods in Hoagland's nutrient solution.

Among the test pesticides MSMA was observed to be the most effective clastogenic as well as turbagenic agent followed by endosulfan, chlorpyriphos and asulum respectively in that order. 
Acknowledgements

\section{B. V. Rao is grateful to UGC (SAP), New Delhi for Junior and Senior Research Fel- lowships.}

\section{References}

Amer, S. M. and Farah, O. R. 1976. Cytological effects of pesticides VIII. Effects of the carbamate pesticides "IPC", 'Rogor' and 'Duphar' on Vicia faba. Cytologia 41: 597-606.

- and - 1983. Cytological effects of pesticides XII. Effects of the phosphorothioate insecticide Dursaban on the mitosis of Vicia faba. Cytologia 48: 27-33.

-, - and Fahmy, M. A. 1980 . Cytogenetic effects of the insecticide $O, O$-diethyl $O$-(3, 5, 6-trichloro-2 pyridyl) phosphorothioate (Dursaban). Europ. J. Cell Biol. 22: 571.

Badr, A. 1983. Cytogenetic activities of triazine herbicide in root tips of Allium cepa and Vicia faba. Mutat. Res. 117: 173-182.

Bedford, C. T. and Robinson, J. 1972. The alkylating properties of organophosphates. Xenobiotica 2: 307337.

Brogger, A. 1979. Chromosome damage in human mitotic cells after in vivo and in vitro exposure to mutagene. In Genetic Damage in Man Caused by Enivronmental Agents (Ed. Berg). Academic Press, N. Y. pp. 87-99.

Constantin, M. J. and Owens, E. T. 1982. Introduction and perspectives of plant genetic and cytogenetic assays. Mutat. Res. 99: 1-12.

Crosby, G. D. 1981. Pesticides as Environmental Mutagens in Genetic Toxicology: An Agricultural Perspective (eds.) Fleck R. A. and Hollander A. Plenum Press, N. Y. pp. 201.

Darlington, C. D. and La Cour, L. E. 1976. The Handling of Chromosomes (6th Edn.) Allen and Unwin, London, pp. 201.

de Kergommeaux, D. J., Grant, W. F. and Sandhu, S. S. 1983. Clastogenic and physiological responses of chromosomes to nine pesticides in the Vicia faba in vivo root tip assay system. Mutat. Res. 124: 6984.

Epstein, S. S. and Legator, M. S. (ed.) 1971. The Mutagenicity of Pesticides: Concepts and Evaluation. MIT Press, Cambridge, pp. 220.

Fishbein, L. 1972. Pesticidal, industrial, food additive and drug mutagens. In H. E. Sutton and M. I. Harris (eds.). Mutagenic Effects of Environmental Contaminants. Academic Press, New York, pp. 129170.

Fourcade, M. F., Berger, C. A. and Witkus, E. R. 1963. Cytological effects of aminopyrine. Caryologia 16: 347-351.

Grant, W. F. 1978. Chromosomal aberrations in plants as a monitoring system. Environ. Hlth. Persp. 27: $37-43$.

Grover, I. S. and Tyagi, P. S. 1979. Induction of chlorophyll mutants by some common pesticides. Indian J. Exp. Biol. 17: 609-611.

- 1980a. Cytological effects of some common pesticides in barley. Environ. Exp. Bot. 29: 37-43.

- 1980b. Chromosome aberrations induced by pesticides in meiotic cells of barley. Carylologia 33: 251-259.

Ma, T. H. 1981. Tradescantia micronucleus bioassay and pollen tube chromatid aberration test for in situ monitoring and mutagen screening. Environ. Hlth. Persp. 27: 85-90.

McGill, M., Pathak, S. and Hsu, T. C. 1974. Effects of ethidium bromide on mitosis and chromosomes: A possible amaterial basis for chromosomal stickiness. Chromosoma 47: 157-167.

Rosenkranz, H. S. and Rosenkranz, S. S. 1972. Reaction of DNA with phosphoric acid esters: gasoline additives and insecticides. Experientia 28: 386-387.

Sharma, C. B. S. R. 1983. Plant meristems as monitors of genetic toxicity of environmental chemicals. Curr. Sci. 52: 1000-1002.

Sparrow, A. H. and Singleton, W. R. 1953. The use of radio-cobalt as a source of gamma-rays and some effects of chronic irradiation on growing plants. Amer. Nat. 87: 29-48.

Tomkins, D. J. and Grant, W. F. 1972. Comparative cytological effects of the pesticides Menzon, Metrobromuron and tetra chloroisophalonitile in Hordeum and Tradescantia. Can. J. Genet. Cytol. 14: 245256.

Wooder, M. F. and Wright, A. S. 1981. Alkylation of DNA by organophosphorus pesticides. Acta Pharmacol. Toxicol 49: 51-55.

Wuu, K. D. and Grant, W. F. 1966. Morphological and somatic aberrations induced by pesticides in barley (Hordeum vulgare). Can. J. Genet. Cytol. 8: 481-501. 